\title{
"SISTEM EKONOMI KAPITALIS"
}

\section{Nur Evi Susanti (90100118039)}

\section{Pengertian Sistem Ekonomi Kapitalisme}

Sistem ekonomi merupakan suatu cara yang di gunakan untuk mengorganisasikan dan mengatur semua aktivitas ekonomi di masyarakat baik yang dilakukan oleh swasta maupun pemerintah.di dasarkan pada prinsip tertentu untuk mencapai kesejahtraan dan kemakmuran. ${ }^{1}$.Sedangkan kapitalisme merupakan suatu sistem organisasi ekonomi yang memiliki ciri-ciri yaitu hak milik pribadi atas distribusi dan alat-alat produksi yang manfaat untuk mencapai keuntungan dalam kondisi yang sangat kompetitif ${ }^{2}$

Jadi sistem ekonomi kapitalis adalah sistem ekonomi yang asset-aset produktif dan atau faktor-faktor produksinya sebagian besar dimiliki oleh sektor individu atau swasta. perekonomian yang memberikan kebebasan secara penuh kepada setiap orang untuk melaksanakan kegiatan perekonomian seperti memproduksi barang, menjual barang, menyalurkan barang dan lain sebagainya . ${ }^{3}$

Sistem kapitalis memandang bahwa manusia adalah pemilik satu-satunya terhadap harta yang telah diusahakan. Tidak ada hak orang lain di dalamnya. Ia memiliki hak mutlak untuk membelanjakan sesuai dengan keinginannya. Sosok pribadi dipandang memiliki hak untuk memonopoli sarana-sarana produksi sesuai kekuasaannya. Ia mengalokasikan hartanya hanya pada bidang yang memiliki nilai guna materi (profit oriented).$^{4}$

Pemikiran ekonomi kapitalisme ini erat hubungannya dengan teori Adam Smith mengenai Invisible Hand, dalam bukunya An Inquiry into the Nature and Causes of the Wealth of Nation. Dalam bukunya inilah Adam Smith pertama kali merumuskan pemikiran mengenai ekonomi kapitalis. Adam Smith mendasarkan

${ }^{1}$ Effendi, S. (2019) . Perbandingan Sistem Ekonomi Islam Dengan Sistem Ekonomi Kapitalis dan Sosialis. JRAM (Jurnal Riset Akuntansi Multiparadigma), 6(2), 147-158.

${ }^{2}$ Agustiati, Agustiati. 2009. "Sistem Ekonomi Kapitalisme." Academica 1(2).

${ }^{3}$ Itang, Itang, and Adib Daenuri. 2017. "Sistem Ekonomi Kapitalis, Sosialis, Dan Islam.” Tazkiya 18(01): $67-91$.

${ }^{4}$ Effendi, S. (2019) . Perbandingan Sistem Ekonomi Islam Dengan Sistem Ekonomi Kapitalis dan Sosialis. JRAM (Jurnal Riset Akuntansi Multiparadigma), 6(2), 147-158. 
sistem ini terhadap sistem kebebasan alami, dimana setiap individu diberi kebebasan untuk mengejar kepentingannya masing-masing. ${ }^{5}$

\section{Ciri-Ciri Sistem Kapitalis}

\section{Kebebasan Memiliki Harta Secara Perorangan}

Hak milik perorangan merupakan elemen penting kapitalisme. Dalam paham kapitalisme tidak berlaku istilah hak milik berfungsi sosial. Pemberian hak milik secara mutlak akan menciptakan perilaku individu untuk menggunakan semaksimal mungkin sumber daya yang dimiliki dan berdampak pada distribusi pendapatan masyarakat.

2. Kebebasan ekonomi dan persaingan bebas

Setiap individu berhak untuk mendirikan, mengorganisasi dan mengelola perusahaan yang diinginkan. Individu juga berhak terjun dalam semua bidang perniagaan dan memperolah keuntungan sebanyak-banyaknya. Negara tidak boleh campur tangan dalam semua kegiatan ekonomi dan persaingan bebas yang berorientasi mencari keuntungan, selama aktifitas yang dilakukan itu legal menurut perundang-undangan yang berlaku di negara tertentu. Persaingan bisa terjadi antar produsen dalam menghasilkan produk, antar penyalur produk, antar karyawan untuk mendapatkan pekerjaan, bahkan antar pemilik modal, dan seterusnya.

3. Mementingkan diri sendiri.

Aktivitas individu diyakini tidak akan membawa kekacauan, bahkan sebaliknya akan membawa kemakmuran bangsa-bangsa.Adam Smith mengatakan "Bukan berkat kemurahan hati tukang daging,tukang pembuat bir dan tukang roti kita dapat makan siang, akan tetapi karena mereka memperhatikan kepentingan pribadi mereka. Kita bicarakan bukan kepada rasa kemanusiaan mereka melainkan cinta mereka kepada diri mereka sendiri" 6

4. Perekonomian diatur oleh mekanisme pasar

\footnotetext{
${ }^{5}$ Rustam Dahar KAH, “Teori Invisible Hand Adam Smith dalam Perspektif Ekonomi Islam”, Jurnal economica, Volume 2, Edisi 2, 2012, hal 59

${ }^{6}$ Azhar, A. (2017). Antara Ekonomi Islam Dan Ekonomi Konvensional. Islamika: Jurnal Ilmu-Ilmu Keislaman, 17(2), 1-16.
} 
Setiap harga barang yang ada dipasar sudah ditentukan oleh permintaan dan penawaran yang dilakukan secara bebas

5. Manusia dipandang sebagai mahluk homo-economicus

Manusia yang selalu mengejar kepentingan (keuntungan) sendiri . ${ }^{7}$

6. Campur tangan pemerintah minimum

Dalam sistem ekonomi kapitalis, yang sangat berperan adalah individu, bukan pemerintah. Pihak Pemerintah memberikan kebebasan kepada para pemodal untuk mengembangkan usahanya. Mereka dapat menguasai dan memajukan berbagai aspek ekonomi. Pembangunan sarana jalan, transportasi, berbagai gedung pemerintah dan usaha lainnya ditanangi oleh pihak swasta. Pemerintah tugasnya membuat regulasi untuk membayar pajak yang besar. Hasil dari pajak itulah digunakan untuk mensejahterakan rakyatnya Dengan kata lain, bahwa dalam sistem ini pemerintah bisa turut ambil bagian untuk memastikan kelancaran dan keberlangsungan kegiatan perekonomian yang berjalan, tetapi bisa juga pemerintah tidak ikut campur dalam ekonomi. ${ }^{8}$

\section{DAFTAR PUSTAKA}

Agustiati, Agustiati. 2009. "Sistem Ekonomi Kapitalisme.” Academica 1(2).

Azhar, A. (2017). Antara Ekonomi Islam Dan Ekonomi Konvensional. Islamika: Jurnal Ilmu-Ilmu Keislaman, 17(2), 1-16.

Effendi, S. (2019) . Perbandingan Sistem Ekonomi Islam Dengan Sistem Ekonomi Kapitalis dan Sosialis. JRAM (Jurnal Riset Akuntansi Multiparadigma), 6(2), 147-158.

Itang, Itang, and Adib Daenuri. 2017. "Sistem Ekonomi Kapitalis, Sosialis, Dan Islam." Tazkiya 18(01): 67-91.

Mujiatun, Siti. 2014. "Peran Pemerintah Tentang Pengembangan Perekonomian Dalam Perspektif Sistem Ekonomi Kapitalis, Sosialis, Dan Islam.” Jurnal Analytica Islamica 3: 90-107

Rustam Dahar KAH, “Teori Invisible Hand Adam Smith dalam Perspektif Ekonomi Islam”, Jurnal economica, Volume 2, Edisi 2, 2012, hal 59

\footnotetext{
${ }^{7}$ Mujiatun, Siti. 2014. "Peran Pemerintah Tentang Pengembangan Perekonomian Dalam Perspektif Sistem Ekonomi Kapitalis, Sosialis, Dan Islam.” Jurnal Analytica Islamica 3: 90-107

${ }^{8}$ Effendi, S. (2019) . Perbandingan Sistem Ekonomi Islam Dengan Sistem Ekonomi Kapitalis dan Sosialis. JRAM (Jurnal Riset Akuntansi Multiparadigma), 6(2), 147-158.
} 